\title{
Impact of Self Efficacy on Motivation and Performance of Employees
}

\author{
Jacob Cherian ${ }^{1} \&$ Jolly Jacob ${ }^{2}$ \\ ${ }^{1}$ Department of Management, College of Business Administration, Abu Dhabi University, Abu Dhabi, UAE \\ ${ }^{2}$ Department of Applied Sciences, College of Arts and Sciences, Abu Dhabi University Abu Dhabi, UAE \\ Correspondence: Jacob Cherian, Department of Management, College of Business Administration, Abu Dhabi \\ University, Abu Dhabi, UAE. E-mail: jacob.cherian@adu.ac.ae
}

Received: April 22, 2013 Accepted: May 21, 2013 Online Published: June 18, 2013

doi:10.5539/ijbm.v8n14p80 URL: http://dx.doi.org/10.5539/ijbm.v8n14p80

\begin{abstract}
The aim of this study is to perform a meta-analysis which analyses the individual research findings which pertain to the relationship between self-efficacy, employee motivation and work related performance of the employee. From the results of the study it is observed that self-efficacy theory can be applied for work related performance in terms of motivating different employee related facets as well as organizational pursuits. In this study the researcher has attempted to assess the influence of self-efficacy on the performance of individuals at workplace and the mechanism by which self-efficacy of an individual determines his/her work related performance and motivation. Thus, it becomes necessary to identify the practical implications of the outcomes related to improving employee self-efficacy in order to motivate them and improve their performance.
\end{abstract}

Keywords: self efficacy, motivation, leadership, training, employee productivity, career development

\section{Introduction}

Albert Bandura's social cognitive theory that was published in the year 1986 focuses mainly on the concept of self-efficacy, which is considered as "one of the most theoretically, heuristically and practically useful concepts formulated in modern psychology" (Betz et al., 1996, p. 47). Other authors have also given their opinions on self-efficacy. For example, Lent et al. (1996) states that self-efficacy actually refers to "people's judgment of their capabilities to organize and execute courses of action required attaining designated types of performance" (p. 83). The foundation for personal achievements, personal well being and human motivation is provided by self-efficacy. Bandura (1977) regards the role of self-efficacy beliefs in human functioning as "people's level of motivation, affective states, and actions are based more on what they believe than on what is objectively true" (p. 2).

Self-efficacy has an impact on an individual's emotional reactionsand thought patterns. Self-efficacy can also be described as a function of self beliefs with which individuals can accomplish a task (Bandura, 1986). Thus it can be said that high perseverance that is associated with self-efficacy will most definitely lead to increased performance and productivity. Self-efficacy has proven to be good measurement with which to predict behavioural outcomes when compared to any other motivational construct, especially in psychology and education (Graham \&Weiner, 1996). Denise Rousseau endorsed the recent book on Psychological Capital by Luthanset al., (2008) and stated "it shows how recent breakthroughs in the positive psychology movement can translate into benefits for companies, managers, and workers."

\subsection{Concepts of Self Efficacy}

According to Bandura (1977), "self-concept reflects people's beliefs in their personal efficacy." There are a number of factors that influence an individual's general outlook on life such as self esteem, concepts of self etc. Moreover another study also suggested that self efficacy may be related to task based self esteem (Carson et al., 1997). This is further reiterated by Haycock et al., (1998) in another study. By developing and building self esteem, employees are able to increase their strength in light of frustrations and get self-confirmation (Tjosvold\&Tjosvold, 1995). Thus it can be seen that self efficacy plays an important role in changing and affecting an individual's behaviour.

Several academic researches that have proven that self efficacy is related to self control, resilience in the face of failure, the performance and task efforts and effective problem solving (Bandura, 1986; Gist \& Mitchell, 
1992; Hysong\& Quinones, 1997; Prussia, Anderson, \&Manz, 1998; Stajkovic\&Luthans, 1998). It is likely that a person's 'high' in self-efficacy would surpass less efficacious individuals in relation to factors such as promotions or career success or salary. The current study shows that the above mentioned factors are related to self efficacy. A variety of studies that have carried out researches on the subject of self-efficacy have discovered that it mediates the relation between self-leadership strategies and performance (Prussia et al., 1998) and also between verbal persuasion, performance attainment, ambition and physiological arousal (VanVianen, 1999).

\subsection{Self Efficacy and Employee Performance}

Success in a realm is closely linked to self-efficacy in the realm (Bandura, 1997). Higher self-efficacy in a realm is associated with good outcomes, ranging from greater job satisfaction and performance (Judge \& Bono, 2001), to better physical and mental health (Bandura, 1997), to better academic performance (Bandura, 1997; Robbins et al., 2004). For example, students with higher academic self-efficacy show better academic performance (Robbins et al., 2004). Priming a high self-efficacy component of a self-schema for a realm might result in outcomes similar to those found for individuals who have characteristically high self-efficacy in a realm. Related to this notion, previous research in other areas indicates that manipulating individuals' perceptions with respect to motivation will have an impact on their performance (DeDonno\&Demaree, 2008).

Job involvement and organizational commitment measures have been found to have an impact on employee motivation (Blau, 1988). Any impact on an employee's commitment to her career is found to be associated with his ability to link his motivation to her performance levels and an antecedent to this motivation is his self-efficacy (Morrow, 1993). There has been a great deal of importance given in research to the level of commitment an employee gives to his career. This is important as a career is not only a source of income for the individual to sustain but also one which presents a great deal of occupational meaning as well as continuity as well ensuring a great deal of employment security (Aryee et al., 1994). An individual's behaviour is associated with the degree of commitment he shows to his career. Any individual who has the ability to show commitment to his career always is found to make an attempt to improve his skills and motivate himself to perform well. Such an employee is also found to spend time in terms of developing his skills (Aryee\& Tan, 1992) and promoting his self efficacy by showing better job involvement (Blau 1989).

There has been a great deal of evidence which has linked the importance of employee self efficacy and his performance including the ability to adapt to advanced technologies in the workplace like internet or new software (Hill et al., 1987), ability to cope with current changes in career plan (Stumpf et al., 1987), ability to generate new ideas and grow to a managerial level (Gist, 1989), ability to perform better as a team (Wood et al., 1990), ability to acquire more skills (Mitchell et al., 1994). There have been a number of reviews which have examined the impact of self efficacy on organizational settings however there have been very few which has examined the overall impact on employee performance as well as once which links self efficacy directly to motivation hence performance. Previous studies have shown that both self efficacy and motivation are both integral part of performance and both these factors contribute to a good service quality, effectiveness and efficiency in the workplace.

Despite the significant amount of efforts from the academic community on understanding conscientiousness-performance relationship "very little research has examined the mechanisms through which personality traits influence performance" (Barrick et al., 2002, p. 43). Thus in general it can be stated that self efficacy could be a precursor to career commitment. The present study tries to answer whether self efficacy affects motivation and performance of employees. Thus it can be assumed that there might be a degree of association between motivation, employee performance and self efficacy. In consistent with previous studies, the current review hypothesize that "self-efficacy may be considered a factor positively contributes to the employee morale and in turn productivity". The aim of this study is to perform a review which aggregates and analyzes the individual research findings which pertain to the relationship between self efficacy, employee motivation and work related performance of the employee.

\section{Research Methodology}

A wide range of search methodologies were examined by the researcher in order to identify relevant published and unpublished studies. The researcher reviewed the literature from the period $2000-2012$. To identify relevant studies, we began by performing database searches using the keywords: "self-efficacy," "employee", "motivation," "performance", "satisfaction" "engagement" "leadership" using the Google scholar, Emerald fulltext, and Science Direct and Web of Science databases. The researcher independently extracted data using standardized data extraction forms. When any doubts or conflicts arose they were resolved by consensus or, when necessary, by a second reviewer. Reviewers extracted information on study design. 


\subsection{Inclusion Requirements}

The main requirement for inclusion in this review was that

1) Authors had to have examined impact of self efficacy in moderating employee's perception as an independent variable to determine the effectiveness of the same in impacting their performance levels.

2) This study ensured that the definition of self efficacy adopted in any of the operational variables was according to the definition of Bandura (1977). The two main aspects of self efficacy which were considered were self efficacy magnitudes, self efficacy strength"'

3) With respect to employee performance the researcher ensured that task performance for work related attributes was identified.

4) Include motivation related concepts that fit our conceptualization

5) Report results of an empirical study,

6) Employ a field sample (employees working either full or part time),

7) Report findings in the English language.

\subsection{Results and Discussion}

The summary of research articles which have been collected for this study has been given in Table 1. The different articles are then reviewed chronologically.

Table 1. Summary of chosen articles

\begin{tabular}{|c|c|c|c|c|}
\hline Reference & Area of study & $\begin{array}{l}\text { Research } \\
\text { Method }\end{array}$ & $\begin{array}{c}\text { Study } \\
\text { sector/location }\end{array}$ & Dependent (D)/ Independent (ID) \\
\hline $\begin{array}{l}\text { Luthans \& } \\
\text { Peterson (2002) }\end{array}$ & Leadership & $\begin{array}{l}\text { Quantitative } \\
\text { approach }\end{array}$ & $\begin{array}{l}\text { Different } \\
\text { sectors/England }\end{array}$ & $\begin{array}{l}\text { ID: Manager self-efficacy } \\
\text { D: Employee performance and motivation }\end{array}$ \\
\hline $\begin{array}{l}\text { Day \&Allen } \\
\text { (2004) }\end{array}$ & $\begin{array}{c}\text { Career } \\
\text { commitment \& } \\
\text { development }\end{array}$ & $\begin{array}{l}\text { Quantitative } \\
\text { approach }\end{array}$ & Public sector/USA & $\begin{array}{l}\text { ID: Mentoring } \\
\text { D:Self efficacy, Career development }\end{array}$ \\
\hline Tai (2006) & Training & $\begin{array}{l}\text { Quantitative } \\
\text { approach }\end{array}$ & IT/China & $\begin{array}{l}\text { ID: training framing } \\
\text { D: Employee self-efficacy and motivation }\end{array}$ \\
\hline $\begin{array}{l}\text { Al-Eisa } \\
(2009)\end{array}$ & Training & $\begin{array}{l}\text { Quantitative } \\
\text { approach }\end{array}$ & $\begin{array}{l}\text { Public sector/Saudi } \\
\text { Arabia }\end{array}$ & $\begin{array}{l}\text { ID: Self efficacy, motivation, supervisor } \\
\text { support } \\
\text { D: learning transfer intention }\end{array}$ \\
\hline Ballout (2009) & $\begin{array}{c}\text { Career } \\
\text { commitment \& } \\
\text { development }\end{array}$ & $\begin{array}{l}\text { Quantitative } \\
\text { approach }\end{array}$ & Banking/Lebanon & $\begin{array}{l}\text { ID: Career commitment } \\
\text { D: self-efficacy }\end{array}$ \\
\hline $\begin{array}{l}\text { Mayfield \& } \\
\text { Mayfield }\end{array}$ & Leadership & $\begin{array}{l}\text { Quantitative } \\
\text { approach }\end{array}$ & Healthcare & $\begin{array}{l}\text { ID: Leadership motivating language- } 20 \% \\
\text { improvement of employee performance }\end{array}$ \\
\hline & & & & $\begin{array}{l}\text { D: Employee self-efficacy and performance- } \\
10 \% \text { improvement in performance }\end{array}$ \\
\hline $\begin{array}{l}\text { Liu et al., } \\
(2010)\end{array}$ & Leadership & $\begin{array}{l}\text { Quantitative } \\
\text { approach }\end{array}$ & $\begin{array}{l}\text { Employees from } \\
\text { different } \\
\text { sectors/China }\end{array}$ & $\begin{array}{l}\text { ID: Transformational leadership and } \\
\text { self-efficacy } \\
\text { D: employee job satisfaction, motivation and } \\
\text { performance }\end{array}$ \\
\hline Niu (2010) & $\begin{array}{c}\text { Career } \\
\text { commitment \& } \\
\text { development }\end{array}$ & $\begin{array}{l}\text { Quantitative } \\
\text { approach }\end{array}$ & $\begin{array}{l}\text { Hospitality } \\
\text { sector/Taiwan }\end{array}$ & $\begin{array}{l}\text { ID: Self efficacy } \\
\text { D: Career commitment }\end{array}$ \\
\hline $\begin{array}{l}\text { Leon-Perez } \\
\text { et al., }(2011)\end{array}$ & $\begin{array}{l}\text { Dispute } \\
\text { handling }\end{array}$ & $\begin{array}{l}\text { Quantitative } \\
\text { approach }\end{array}$ & NA & $\begin{array}{l}\text { ID: Self efficacy } \\
\text { D:Objective and subjective transactions and } \\
\text { disputes }\end{array}$ \\
\hline
\end{tabular}




\begin{tabular}{|c|c|c|c|c|}
\hline \multirow[t]{2}{*}{$\begin{array}{l}\text { Ghafoor } \\
\text { et al., (2011) }\end{array}$} & Leadership & $\begin{array}{l}\text { Quantitative } \\
\text { approach }\end{array}$ & Banking/Pakistan & $\begin{array}{l}\text { ID: Transformation leadership, performance } \\
\text { orientation }-r=0.176, p<0.05 \text { ) }\end{array}$ \\
\hline & & & & D: Self efficacy, creativity $-r=0.180, p<0.05$ \\
\hline \multirow[t]{2}{*}{$\begin{array}{l}\text { Olusola } \\
(2011)\end{array}$} & $\begin{array}{l}\text { Employee } \\
\text { productivity }\end{array}$ & $\begin{array}{l}\text { Quantitative } \\
\text { approach }\end{array}$ & $\begin{array}{l}\text { Manufacturing/ } \\
\text { Nigeria }\end{array}$ & $\begin{array}{l}\text { ID: Self efficacy, intrinsic motivation, job } \\
\text { satisfaction- } \mathrm{R}=.986 ; \mathrm{R} 2=.971 ; \mathrm{R} 2 \text { (adj) } \\
=971 ; \mathrm{F}(3,284)=3211.818 ; \mathrm{p}<.05\end{array}$ \\
\hline & & & & D:Employee productivity \\
\hline \multirow{2}{*}{$\begin{array}{l}\text { Pan et al., } \\
(2011)\end{array}$} & Employee & Quantitative & Manufacturing/ & ID: Self efficacy, supervisory support \\
\hline & productivity & & China & D: Employee productivity, job satisfaction \\
\hline \multirow[t]{2}{*}{ Judeh (2012) } & Employee & Quantitative & IT/ Jordan & ID: Job characteristics, self-efficacy \\
\hline & & & & D: Employee performance \\
\hline \multirow{2}{*}{$\begin{array}{l}\text { Chaudhary } \\
\text { et al., (2012) }\end{array}$} & Employee & & India & ID: HRD climate \\
\hline & & & & D: Self efficacy, employee engagement \\
\hline
\end{tabular}

A theoretical understanding of the employee engagement is done in a study by Luthans et al., (2002). The study has a sample population of 170 managers whose psychological state of self-efficacy is evaluated in order to see if they have an impact on the relationship between their employees' measured engagement and a multiple measure of the managers' effectiveness. The results of the study show that the self efficacy does play a mediating role in the relationship between managers rated effectiveness and an employee's engagement. Therefore there is ample evidence that show there exists a strong relationship between self efficacy of managers and employee's engagement and this relationship plays a vital role in a manger's effectiveness. Implications for effective management development and practice are discussed.

The study by Day\& Allen (2004) analysed the impacts of motivation and self-efficacy in improving the work related performance of the employees. The link between career mentoring and successful performance is found to be extremely mediated through career motivation whereas this link is only slightly moderated through career self-efficacy. This is the first study that illustrates the inter-link among mentoring, career self-efficacy, career motivation and indicators of career success.

The aim of the study by Tai (2006) identified the impact of training framing on the motivation and self efficacy of employees. The findings indicate that supervisor training was found to impact employee self efficacy and motivation and ultimately affected their reaction, learning and transfer motivation. Objective measures were a part of the study design along with longitudinal self reports. Relevant information was collected from a team of employees (126) who were attending a training program meant for introduction of computer software operation and design. During the course of the training program, the attendees were asked to take the survey and answer questions at different points like the beginning of the program, middle of the program and the end of the program. The trainees learning performances were obtained after the final session of the training program. The analysis of the results indicated that the training framing had a significant positive impact on the employees training motivation and training self efficacy. This study did not take into account some contextual determinants including post training accountability and organizational climate which is a limitation which needs to be acknowledged.

The study by Al-Eisa et al (2009) aimed at understanding the effect of self efficacy, supervisor support and motivation on transfer intention. The results identified that motivation to learn was found to have a direct impact on learning transfer and mediates the relationship of self efficacy and transfer intention.

The study by Ballout (2009) examined the impact of self efficacy on employee career commitment. The study identified that self efficacy and career commitment were positively linked and impacted employee performance.

From the study of Kellet et al., (2009) the impact of collective efficacy and self efficacy on performance of an employee and his career development was identified. The results of the study indicate that collective efficacy rather than self efficacy had a direct impact on task performance of an employee and his career development.

The study by Mayfield and Mayfield (2009) examined the impact of leadership language as a motivator of employee self efficacy and performance. The study results indicate that there is a direct relationship between the proposed variables. The study shows that the employee self efficacy improves $34 \%$ by leader motivating 
language.

The study by Liu et al., (2010) examined the association between leadership, self efficacy and employee satisfaction. The results indicate that self efficacy of the leader mediates the relationship between leadership and employee satisfaction and performance.

Niu (2010) examined the link between self-efficacy and career commitment of 1025 employees of foodservice industry. This link has been confirmed through the ANOVA of survey data. Positive correlation between self-efficacy and career commitment has been identified using a chi-square test. In this study, the employees with higher self-efficacy were found to be highly committed in their job.

The relationship between employee self efficacy and ability to manage transactions and disputes is examined in the study by Leon-Perez et al., (2011). The study results suggest that higher self efficacy and motivation enabled better ability to deal with transactions and disputes.

Self-efficacy, intrinsic motivation and job satisfaction were factors that was studied by Olusola (2011) in order to investigate their influence on industrial workers performance in order to discover a way to increase employees' productivity in Nigerian industrial settings. The research study's results indicated two things. The first identified that self-efficacy, intrinsic motivation and job satisfaction will predict the job performance of industrial workers. The second presented the idea that each of these variables will predict the job performance of workers.

The link between transformational leadership, learning ability and creativity of the employees has been studied by Ghafoor et al., (2011). In addition to that the mediating impacts of self-efficacy on the link between these factors have also been examined in this study. Ghafoor et al., (2011) have collected data from a sample of 176 employees and managers from banking industry and confirmed the relationship between these factors. This study confirmed that the relationship between performance and creativity of the employees is extremely moderated by self-efficacy and there is no such mediation in the case of relationship between transformational leadership and creativity of the employees.

In China, there has been a study on the impact of self-efficacy of 226 employees who were from four different manufacturing firms (Pan et al, 2011). It was identified from this study that supervisory mentoring is determined by the self-efficacy of an employee. The impacts of supervisory mentoring on work related performance and job satisfaction are moderated by self-efficacy via personal learning. Thus, there exists a positive correlation between the self-efficacy of an employee and mediated effect on work related performance. However, self-efficacy and the mediated effect on job satisfaction are found to be negatively correlated.

The performance at an organisational level, individual level and at a team level all have been significantly influenced by improvements in the work engagement according to a study by Chaudhary et al., (2012). The primary objective of the current study is to determine the effects of occupational self efficacy and human resource development in relation to work engagement among the business executives who are working in various organizations across India. Furthermore the study also strives to delve into the influence of HRD on the work engagement and self efficacy relationships. For the current study a sample of 150 individuals from various spheres of the business world including private sector manufacturing and public sector manufacturing were taken. Information was collected by using online surveys and by direct face to face contact. The study discovered significant relationships among the numerous variables. All the study hypotheses were supported and the environment surrounding the human resource departments was found to play a role in occupational self-efficacy and work engagement.

Judeh (2012) evaluated whether the characteristics of a job had any influence or impact on the workers performance and self efficacy. The authors utilized a methodology that consisted of a questionnaire based survey in which 279 respondents working for corporations listed in technology and communication sector in Amman Stock Exchange participated. In order to check whether the gathered information supported the researcher's proposed model, a Structural Equation Modelling technique which is a statistics based technique was utilized. The analysis of the results indicated that job characteristics did have an impact on job performance and self efficacy; however there was no conclusive evidence that showed that self efficacy had an influence on job performance.

\section{Conclusion}

Thus it is observed from the above studies that self-efficacy theory can be applied for work related performance as well as organizational pursuits. As a result most of the management scholars and experts are interested in this theory. This is found to be related to views in literature. A lot of studies have concentrated on the student's learning efficacy with minimal focus on employees (Gist \& Mitchell, 1992; Johnson, 2005; Joo et al., 2000; 
Stumpf et al., 1987; Zimmerman et al., 1992; Zhao \& Seibert, 2005). In addition to this individuals who have a high self efficacy are more likely to set themselves challenging goals which are most often achieved (Bandura \& Locke, 2003; Stajkovic, 2006).

Thus, it becomes necessary to identify the practical implications of the outcomes related to improving employee self efficacy in order to motivate them and improve their performance. The following implications are made by the author.

Firstly, performance of the employees is positively influenced by the overall self-efficacy. It is also proved that the organizational behaviour of the sceptical practicing professionals is usually influenced a significant amount of confidence. Secondly, complexity of the tasks as well as performance locus is found to moderate the link between self-efficacy and performance at workplace. These two factors play an important role in organizational settings as they have a tendency to deteriorate the link between self-efficacy and performance. With the increase in the complexity of task, this link has been proved to be weaker. However, the organizations can improve the performance of the employees with the help of the following suggestions:

Firstly, the employees should be provided with relevant details of the tasks assigned to them. The exact definitions and explanations of the tasks and context of tasks would help them to deal with the complex tasks.

Secondly, the managers should explain them about the technical skills required for successful performance. They should also instruct the employees how to select a proper method among the available methods while solving a complex task.

Thirdly, the managers should keep the work environment away from physical distractions. These physical distractions are found to induce negative thoughts, psychological stress and reduce team spirit among the employees. In addition to that the managers should improve the self-efficacy of the employees through effective training initiatives and make them successfully perform the complex tasks. The managers should also improve the cognitive skills and support them in taking up challenging tasks through training.

Researchers have discussed more about the concept of self-efficacy. However, there is no adequate review on the link between self-efficacy and performance at workplace. In order to fill this gap, the researcher has reviewed and analyzed the outcomes of the related literature. These outcomes were found to be related to work related performance. As a result, we should not expect them to reflect the overall of influence of self-efficacy perceptions on other activities. However, the influence of self-efficacy on occupational choice and job searching, health conscious as well as proper physical functioning in sports psychology and medicine, academic performance of the individuals, and flexibility are some aspects which have not been discussed in this study.In this study the researcher has attempted to assess the influence of self-efficacy on the performance of individuals at workplace and the mechanism by which self-efficacy of an individual determines his/her work related performance and motivation.

\section{References}

Al-Eisa, A. S., Furayyan, M. A., \& Alhemoud, A. M. (2009). An empirical examination of the effects of self-efficacy, supervisor support and motivation to learn on transfer intention. Management Decision, 47, 1221-1244. http://dx.doi.org/10.1108/00251740910984514

Aryee, S., \& Tan, K. (1992). Antecedents and outcomes of career commitment. Journal of Vocational Behavior, 40, 288-305. http://dx.doi.org/10.1016/0001-8791(92)90052-2

Aryee, S., Chay, Y. W., \& Tan, H. H. (1994). An examination of the antecedents of subjective career success among a managerial sample in Singapore. Human Relations, 47, 487-509. http://dx.doi.org/10.1177/001872679404700502

Ballout, H. I. (2009). Career commitment and career success: moderating role of self-efficacy. Career Development International, 14. http://dx.doi.org/10.1108/13620430911005708

Bandura, A. (1977). Self-efficacy: Toward a unifying theory of behavioral change. Psychological Review, 84, 191-215. http://dx.doi.org/10.1037/0033-295X.84.2.191

Bandura, A. (1986). Social foundations of thought and action: A social cognitive theory. Englewood Cliffs, NJ: Prentice-Hall.

Bandura, A. (1997). Self-Efficacy: The Exercise of Control. New York: W. H. Freeman.

Bandura, A., \& Locke, E. A. (2003). Negative self-efficacy and goal effects revisited. Journal of Applied Psychology, 88(1), 87-99. http://dx.doi.org/10.1037/0021-9010.88.1.87 
Barrick, M. R., Stewart, G. L., \& Piotrowski, M. (2002). Personality and job performance: Test of the mediating effects of motivation among sales representatives. Journal of Applied Psychology, 87(1), 1-8. http://dx.doi.org/10.1037/0021-9010.87.1.43

Betz, N. E., Klein, K. L., \& Taylor, K. M. (1996). Evaluation of a short form of the Career Decision-making $\begin{array}{lllll}\text { Self-Efficacy Scale. Journal of Career Assessment, 4, 47. } & \text { 4, }\end{array}$ http://dx.doi.org/10.1177/106907279600400103

Blau, G. (1988). Management and prediction of career commitment. Journal of Occupational Psychology, 32, 227-288.

Blau, G. (1989). Testing gene ralizability of a caree $\mathrm{r}$ commitment measure and its impact on employee turnover. Journal of Vocational Behavior, 35, 88-103. http://dx.doi.org/10.1016/0001-8791(89)90050-X

Carson, K. D., Carson, P. P., Lanford, H., \& Roe, C. W. (1997). The effects of organization-based self-esteem on workplace outcomes: an examination of emergency medical technicians. Pub. Pers. Manage., 26(1), 139-155.

Chaudhary, R., Rangnekar, S., \& Barua, M. K. (2012). Relationships between occupational self efficacy, human resource development climate, and work engagement. Team Performance Management, 18, 370-383. http://dx.doi.org/10.1108/13527591211281110

Day, R., \& Allen, T. D. (2004). The relationship between career motivation and self-efficacy with protégé career success. Journal of Vocational Behavior, 64(1), 72-91. http://dx.doi.org/10.1016/S0001-8791(03)00036-8

DeDonno, M. A., \& Demaree, H. A. (2008). Perceived time pressure and the Iowa Gambling Task. Judgment and Decision Making, 3, 636-640.

Ghafoor, A., Qureshi, T. M., Azeemi, H. R., \& Hijazi, S. T. (2011). Mediating role of creative self-efficacy. African Journal of Business Management, 5, 11093-11103.

Gist, M. E. (1989). The influence of training method on self-efficacy and idea generation among managers. Personnel Psychology, 42, 787-805. http://dx.doi.org/10.1111/j.1744-6570.1989.tb00675.x

Gist, M. E., \& Mitchell, T. R. (1992). Self-efficacy: A theoretical analysis of its determinants and malleability. Academy of Management Review, 17, 183-211.

Graham, S., \& Weiner, B. (1996). Theories and principles of motivation. In D. C. Berliner and R. Calfee (Eds.), Handbook of educational psychology (pp. 63-84). New York: Macmillan.

Haycock, L. A., McCarthy, P., \& Skay, C. L. (1998). Procrastination in college students: the role of self-efficacy and anxiety. Journal of Counseling \& Development, 76, 317-324. http://dx.doi.org/10.1002/j.1556-6676.1998.tb02548.x

Hill, T., Smith, N. D., \& Mann, M. F. (1987). Role of efficacy expectations in predicting the decision to use advanced technologies: The case of computers. Journal of Applied Psychology, 72, 307-313. http://dx.doi.org/10.1037/0021-9010.72.2.307

Hysong, S. J., \& Quinones, M. A. (1997). The relationship between self-efficacy and performance: A meta-analysis. Paper presented at the Twelfth Annual Conference of the Society for Industrial and Organizational Psychology, St. Louis, MO.

Johnson, S. L. (2005). Mania and dysregulation in goal pursuit. Clinical Psychology Review, 25, 241-262. http://dx.doi.org/10.1016/j.cpr.2004.11.002

Joo, Y., Bong, M., \& Choi, H. (2000). Self-Efficacy for self-regulated learning, academic self-efficacy, and internet self-efficacy in web-based instruction. Educational Technology Research \& Development, 48, 5-17. http://dx.doi.org/10.1007/BF02313398

Judeh, M. (2012). Selected Personality Traits and Intent to Leave: A Field Study in Insurance Corporations. International Business Research, 5. http://dx.doi.org/10.5539/ibr.v5n5p88

Judge, T. A., \& Bono, J. E. (2001). Relationship of core self-evaluations traits - selfesteem, generalized self-efficacy, locus of control, and emotional stability - with job satisfaction and job performance: A meta-analysis. Journal of Applied Psychology, 86(1), 80-92. http://dx.doi.org/10.1037/0021-9010.86.1.80

Kellett, J. B., Humphrey, R. H., \& Sleeth, R. G. (2009). Career development, collective efficacy, and individual task performance. Career Development International, 14, 534-546. http://dx.doi.org/10.1108/13620430910997286 
Lent, R. W., Brown, S. D., \& Hackett, G. (1996). Career development from a social cognitive perspective. In Brown and L. Brooks (Eds.), Career choice and Development (3rd ed., pp. 373-422), San Francisco.

Leon-Perez, J. M., Medina, F. J., \& Munduate, L. (2011). Effects of self-efficacy on objective and subjective outcomes in transactions and disputes. International Journal of Conflict Management, 22. http://dx.doi.org/10.1108/10444061111126693

Liu, J., Siu, O., \& Shi, K. (2010). Transformational Leadership and Employee Well-Being: The Mediating Role of Trust in the Leader and Self-Efficacy. Applied Psychology, 56, 454-479.

Luthans, F., Rhee, S., Luthans, B. C., \& Avey, J. B. (2008). Impact of behavioral performance management in a Korean application. Leadership \& Organization Development Journal, 29, 427-443. http://dx.doi.org/10.1108/01437730810887030

Mayfield, M. R., \& Mayfield, J. R. (2009). The role of leader leader-follower relationships in leader communications: A test using the LMX and motivating language models. Journal of Business Inquiry, 8, 65-82.

Mitchell, T. R., Hopper, H., Daniels, D., George-Falvy, J., \& James, L. R. (1994). Predicting Self-Efficacy and Performance during Skill Acquisition. Journal of Applied Psychology, 79, 506-517. http://dx.doi.org/10.1037/0021-9010.79.4.506

Morrow, P. (1993). The theory and measurement of work commitment. Greenwich: JAI Press.

Niu, H. (2010). Erratum to \& ldquo; Investigating the effects of self-efficacy on foodservice industry employees \& rsquo; career commitment. International Journal of hospitality Management, 29, 1336. http://dx.doi.org/10.1016/j.ijhm.2010.03.006

Olusola, O. (2011). Intinsic Motivation, Job Satisfaction And Self-Efficacy As Predictors Of Job Performance Of Industrial Workers In Ijebu Zone Of Ogun State. The Journal of International Social Research, 4.

Pan, W., Sun, L., \& Chow, I. H. (2011). The impact of supervisory mentoring on personal learning and career outcomes: The dual moderating effect of self-efficacy. Journal of Vocational Behavior, 78, 264-273. http://dx.doi.org/10.1016/j.jvb.2010.05.001

Prussia, G. E., Anderson, J. S., \& Manz, C. C. (1998). Self-leadership and performance outcomes: The mediating influence of self-efficacy. Journal of Organizational Behavior, 19, 523-538. http://dx.doi.org/10.1002/(SICI)1099-1379(199809)19:5<523::AID-JOB860>3.0.CO;2-I

Robbins, S. B., Lauver, K., Le, H., Davis, S., Langley, R., \& Carlstrom, A. (2004). Do Psychosocial and Study Skill Factors Predict College Outcomes? A Meta-Analysis. Psychological Bulletin, 130, 261-288. http://dx.doi.org/10.1037/0033-2909.130.2.261

Stajkovic, A. D. (2006). Development of a core confidence higher-order construct. Journal of Applied Psychology, 91, 1208-1224. http://dx.doi.org/10.1037/0021-9010.91.6.1208

Stajkovic, A. D., \& Luthans, F. (1998). Self-efficacy and work-related performance: A meta-analysis. Psychological Bulletin, 124, 240-261. http://dx.doi.org/10.1037/0033-2909.124.2.240

Stumpf, S. A., Breif, A. P., \& Hartman, K. (1987). Self-efficacy expectations and coping with career-related events. Journal of Vocational Behavior, 31, 91-108. http://dx.doi.org/10.1016/0001-8791(87)90037-6

Tai, W. (2006). Effects of training framing, general self-efficacy and training motivation on trainees' training effectiveness. Personnel Review, 35(1), 51-65. http://dx.doi.org/10.1108/00483480610636786

Tjosvold, D., \& Tjosvold, M. M. (1995). Cooperation theory, constructive controversy, and effectiveness: Learning from crises. In Guzzo, R. A., \& Salas, E. (Eds.), Team effectiveness and decision making in organizations (pp. 79-112). San Francisco: Jossey-Bass.

Van Vianen, A. E. M. (1999). Managerial self efficiacy, outcome expectanicies and work-role salience as determinants of ambitions for a managerial position. Journal of applied social pshycology, 29, 639-665. http://dx.doi.org/10.1111/j.1559-1816.1999.tb01406.x

Wood, R., Bandura, A., \& Bailey, T. (1990). Mechanisms governing organizational performance in complex decision making environments. Organizational behavior and human decision process, 46, 181-201. http://dx.doi.org/10.1016/0749-5978(90)90028-8

Zhao, H., Seibert, S. E., \& Hills, G. E. (2005). The mediating role of self-efficacy in the development of

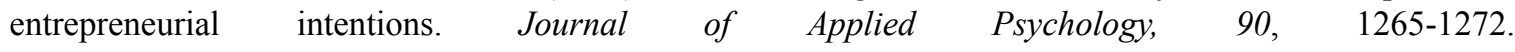


http://dx.doi.org/10.1037/0021-9010.90.6.1265

Zimmerman, B. J., Banudra, A., \& Martinez-Pons, M. (1992). Self-motivation for academic attainment: The role of self-efficacy beliefs and personal goal setting. American Educational Research Journal, 29, 663-676. http://dx.doi.org/10.3102/00028312029003663

\section{Copyrights}

Copyright for this article is retained by the author(s), with first publication rights granted to the journal.

This is an open-access article distributed under the terms and conditions of the Creative Commons Attribution license (http://creativecommons.org/licenses/by/3.0/). 